\title{
Hrvoje Tutek
}

Formalistička estetika

i nacionalni identitet:

prilog materijalističkoj

analizi hrvatske

humanistike u

tranziciji ${ }^{\star}$

* Rad na članku dijelom je omogućen potporom Hrvatske zaklade za znanost kroz projekt "Kulturna povijest kapitalizma: Britanija, Amerika, Hrvatska”. 
Kako bi se shvatio razvoj specifičnih epistemoloških dominanti u mišljenju o književnosti i kulturi u domaćoj humanistici, kao i odredila mjera i funkcija njihove ideologiziranosti prema simptomatičnim mjestima gdje ne dosežu kriterije teorijske dosljednosti, potrebno je historiografski okvir autonomne "povijesti ideja" u kojem se često promatraju $^{01}$ usidriti nekom vrstom metodološkog materijalizma. Drugim riječima, kako bi se propitala autonomija ključnih kategorija humanističkog diskursa o književnosti i kulturi, kako bi se taj diskurs objasnio kao neka vrsta dijalektičke adaptacije kompleksnoj povijesnoj (institucionalnoj, kulturnoj, političko-ekonomskoj) okolini, što je minimalni zahtjev za svaku materijalističku analizu, formaciju njegovih epistemoloških dominanti potrebno je promatrati u njenom dužem trajanju, postavljajući ih u teorijski adekvatne odnose prema povijesnoj dinamici odgovarajućeg društvenog okvira. Pritom su naravno, ključna pitanja kako uopće odrediti granice gorespomenutog "trajanja", što bi bilo "teorijski adekvatno" i koji je društveni okvir "odgovarajući”. Budući da ovdje nemamo mjesta detaljno razrađivati odgovore na svako od njih, a neki od odgovora bit će ionako dani implicitno, spomenimo samo da je otpočetka važno imati na umu da se granice "društvenog okvira", kako će ovdje biti koncipiran, ne poklapaju s nacionalnim granicama ${ }^{02}$. Govor o "domaćoj humanistici” ima smisla samo uvjetno, ako se ona kvalificira u odnosu prema strukturnim ograničenjima svoje šire, transnacionalne povijesne dinamike. A ta su strukturna ograničenja, najopćenitije uzevši, određena specifičnostima modusa regulacije određenog režima akumulacije kapitala te položajem u svjetskom sistemu.$^{03}$ Stoga i nije neobično,

01 Velik broj radova o Zagrebačkoj školi u domaćoj humanistici ne izlazi iz okvira povijesti ideja. Usp. npr. Užarević 1995, 2015 te Car 2009.

02 Zadnjih godina u polju književne i kulturne teorije puno se i s pravom inzistira na transnacionalnim historiografijama. Neke moguće modele transnacionalne materijalističke historiografije književnosti razvili su Franco Moretti sa svojom materijalističkom sociologijom kulturnih formi ili nedavno grupa autora u sklopu Warwick Research Collectivea s teorijom nejednakog i kombiniranog razvoja u svjetskoj književnosti. Cf. WReC 2015, Moretti 2005.

03 Koristim ovdje, uz određen oprez, koncepte (prvenstveno onaj "modusa regulacije”) preuzete od francuske regulacijske škole u političkoj ekonomiji. Oslanjajući se na koncepte regulacijske škole, Mathias Nilges, na čiji rad ćemo se referirati niže, pokušao je nedavno uvesti i koncept "kulturne regulacije" kapitalizma (ona po njemu karakterizira 
kao što ćemo ovdje učiniti, započeti analizu simptomatičnih aspekata posljednjih šezdesetak godina književnoznanstvene i kulturološke tradicije domaće humanistike zaobilazno, tako da pokušamo objasniti jedan suvremeni fenomen iz američkog akademskog polja. Problematika koja iz tog proizađe, poslužit će kasnije kao referentna točka za analizu analognih fenomena u domaćem kontekstu.

\section{(Neo)formalizam u centru: povratak forme}

Konkretan fenomen o kojem je riječ relativno je recentna pojava takozvanog "novog formalizma" unutar kulturne i književne teorije u Sjedinjenim Američkim Državama. Govoreći o tom fenomenu u temeljitoj i preglednoj analizi napisanoj 2007. godine, Marjorie Levinson je ustvrdila da je u slučaju novog formalizma zapravo bolje govoriti o "pokretu" nego o "teoriji ili metodi", i to pokretu koji nije ograničen na specifičnu problematiku usko definiranog stručnog polja ili diskusije o konkretnoj temi, već o pokretu čije je postojanje u SAD-u moguće registrirati u "[cjelini] repertoara književnih i kulturnih studija” (Levinson 2007: 558). Iz ovakve definicije neoformalizma kao pokreta, njegove deklarirane metodološke tendencije prema reaktualizaciji zapuštenih tradicija te poziva na "povratak formi", u prvi plan dolazi urgentnost političke motivacije koja karakterizira taj pokret. On nastaje, može se ustvrditi, kao pokušaj odgovora na ono što se u Sjedinjenim Američkim Državama doživljava kao akutna disciplinarna kriza u postmodernoj humanistici. Njeni uzroci su kompleksni, i o njima će biti još riječi, no spomenimo samo da je to što se danas percipira kao kriza svojedobno imalo auru velike avanture i epohalne dobre prilike. Pojam "postmoderne disciplinarne krize", kako ga najčešće upotrebljavaju oni koji su zbog krize zabrinuti, skriva tu činjenicu, otežava razlikovanje simptoma i uzroka, a postanak krize - nezadovoljavajuće - traži isključivo u procedurama samih disciplina. Iz perspektive spomenute zabrinutosti situacija u suvremenoj američkoj humanistici ugrubo izgleda ovako: na epistemološkoj razini humanističke disciplinarne procedure karakterizira radikalni socijalni konstruktivizam, metodološki se uvelike oslanjaju na teoriju i analizu diskursa preuzetu iz francuske poststrukturalističke teorije, ponajviše od Michela Foucaulta.

zreli post-fordistički vid kapitalističkog razvoja), pri čemu je taj koncept, po Nilgesu, ključan i za razumijevanje koncepta forme koji je središnji u ovom tekstu (cf. Nilges). Širu raspravu o Nilgesovim tezama ovdje nije moguće ponuditi. Za detaljan pregled i kritike izvornih postulata regulacijske škole cf. Brenner i Glick, Jessop i Sum. 
Fokusirane su na analizu proizvodnje i organizacije moći u društvu kroz kompleksni mehanizam diskurzivne interakcije i presijecanja, a politički (kao i historiografski) orijentirane na individualni identitet kao lokus emancipacije. Ova orijentacija na diskurs, pripadajući epistemološki relativizam i temeljita dekonstrukcija polazišnih pretpostavki tradicionalnih humanističkih disciplina dovode do pomicanja njihovih granica i promjene modusa disciplinarne regulacije proizvodnje znanja. Nesigurnost koja zbog toga nastaje, gubitak tradicionalnih ili uopće stabilnih objekata proučavanja, često se u akademskom polju tumači kao gubitak "disciplinarnog identiteta" (Nilges 2009: 70), odnosno čvrstog okvira za proizvodnju znanja unutar humanističkih disciplina.

Vratimo li se ovdje neoformalizmu koji je bez obzira na rasprostranjenost kroz čitav spektar humanističkih disciplina ipak možda najvidljiviji na području teorije književnosti i kulture, gornje pojašnjenje možemo konkretizirati tako da kažemo da je zahtjev za povratkom analizi književne/estetske forme, odnosno zahtjev za povratkom književnosti koji karakterizira neoformalizam, specifična vrsta reakcije na vladavinu iznad opisanih uvjeta i nesigurnosti. Pritom je važno primijetiti da ova nesigurnost dolazi u centar interesa u akademskom polju otprilike u trenutku konvergencije "disciplinarne krize" s posljedicama sve zamjetnije institucionalne krize (ili naprosto transformacije) sveučilišta pod utjecajem neoliberalnih politika (najozbiljnije među tim posljedicama su nezaposlenost $\mathrm{i}$ prekarizacija akademskog $\operatorname{rada}^{04}$ ).

No neoformalizam, koji u tom kontekstu izranja kao pokret, nije homogen i sadrži različite preporuke za konceptualizaciju forme kojoj bi se, navodno, trebalo vratiti. Forma se tako shvaća ili historistički, kao kulturnopovijesno proizveden sklop tehnika koje su uvjet razumljivosti društvenopovijesnih sadržaja, ili naturalistički, kao kognitivno-organizacijski obrazac koji se, objektiviran u odgovarajućem mediju, registrira kao estetsko iskustvo i regulira našu percepciju. Marjorie Levinson na ovim različitim koncepcijama bazira i podjelu neoformalističkog pokreta na dvije skupine - normativni i aktivistički formalizam. Normativni formalizam pritom je konzervativniji i sadrži pokušaj revitalizacije klasične estetike, odnosno inzistira na uspostavi (ili otkriću) koherentnog sustava estetskih normi kao kriterija adekvatnosti znanstvenog interesa za kulturu, te mu je misija

04 O strukturnoj logici akademske nezaposlenosti u globalnom kontekstu vidi Gupta et al. 2016. 
spasiti univerzalizam devetnaestostoljetne građanske estetike od napada suvremenih političkih interpretacija i radikalnog historizma. Za razliku od teorijskog i metodološkog fokusa na probleme društvene funkcije kulturne proizvodnje, on predlaže svojevrsni "povratak lijepom”, odnosno transcendentalnom "estetskom iskustvu" izvan reduktivnih okvira povijesti, društva, ili ideologije. Levinson ga naziva "normativnim" zbog njegove bliskosti Schillerovoj koncepciji estetskog obrazovanja, odnosno zbog uvjerenja da je estetski fenomen na određeni način normativan, pa da je i iskustvo estetskog u svojim kognitivnim i afektivnim dimenzijama iskustvo etičkog normiranja i kao takvo "kulturno-političko" (Levinson 2007: 559). Carolyn Lesjak nadopunjuje ove uvide dobro primijetivši da je normativni formalizam po svom univerzalističkom pristupu, inzistiranju na nesvodivosti estetskog iskustva na učinke povijesnih faktora, te povratku ideji "ljudske prirode", također blizak i novijim sociobiološkim ili evolucijsko-psihološkim koncepcijama "umjetničkog instinkta" (Dutton 2007) koje kao svoju eksplanatornu matricu preuzimaju biološki determinizam (Lesjak 2013). Kao posljedica takvog pristupa u krajnjoj instanci izranja koncept kulturne proizvodnje kao procesa nezavisnog, ili relativno nezavisnog od društvenopovijesnog razvoja.

Aktivistički formalizam, nasuprot tome, pokušava vratiti naglasak unutar samih historističkih istraživanja kulture na pitanje strukture i (recepcijske, političke) dinamike kulturnih formi. Jedna od strategija pritom je i revitalizacija historijsko-materijalističke matrice na putanji Lukács-Adorno-Jameson koja ekscese i aporije utjecaja radikalnijih aspekata socijalnog konstruktivizma postmoderne humanistike pokušava uzemljiti realističkom epistemologijom koja se uvelike oslanja na koncept forme. No općenito uzevši, ovi pokušaji, slično kao i kod normativnog formalizma, prvenstveno su opterećeni pokušajima reaktualizacije zapostavljenih koncepata $\mathrm{i}$ argumenata, svojevrsnom nostalgijom "povratka", a ne težnjom za konceptualnom inovacijom ili dijalektičkom inkorporacijom teorijskih tradicija koje baštine. Unutar polja aktivističkog neoformalizma, ovo je dominantna tendencija i kod pokušaja koji su bliži novom historizmu: čak se i za nedavnu zapaženu knjigu "aktivističke” formalistkinje Caroline Levine, čija eksplicitna tema je upravo teorijska razrada problema forme, teško može reći da se otima gravitaciji pomalo paraliziranog akademskog polja. U knjizi Forms: Whole, Rhythym, Hierarchy, Network, Levine tako pokušava ponuditi nacrt nove analitičke metode koja se sastoji u uočavanju fiksnog i ponovljivog uzorka u kojem je sadržano odre- 
đeno povijesno značenje, a taj uzorak naziva formom. Formu onda definira kao specifičan mehanizam organizacije historijskog iskustva kroz koji društvo proizvodi kompleksne supostojeće poretke, a cilj je projekta da se kroz analizu kulturnih formi kao mehanizama (kognitivne, semantičke) organizacije povijesnog iskustva u cijelom nizu razdvojenih domena, pronađu i razviju forme iskustvene organizacije koje bi pomogle uspostavi pravednijeg društvenog poretka. Ovo, procjenjujemo li uzimajući u obzir deklariranu društveno-transformativnu svrhu pristupa koji predlaže Levine, zvuči kao nacrt jedne dosta apstraktne metode, kao i samouvjereno kulturalističke politike, i to doista jest tako, kao što je vidljivo iz sljedećeg citata:

jedna od stvari nad kojima ljudi imaju kontrolu jesu poreci koje mi sami namećemo: naši prostorni i vremenski aranžmani, naše hijerarhije vrijednosti i mehanizmi distribucije bogatstva - naše forme. [...] Foucault je bio u pravu fokusirajući se na oblike i aranžmane koji strukturiraju iskustvo svakodnevice. No uvjerena sam $\mathrm{u}$ to da je bio u krivu misleći da te forme konvergiraju u masivne režime koordinirane moći ${ }^{05}$. (Levine 2015: xiii)

Upadljiv je u ovome specifičan otklon od Foucaulta koji se ne sastoji u otklonu od fiksacije na analizu moći, već u zazoru od toga da se ta moć promatra kao jedinstven "režim", zazoru od bilo kakve, makar i minimalne totalizacijske teorijske geste. U svom inzistiranju na jednakovrijednosti i dehijerarhiziranosti formalnih aranžmana koje promatra te potrazi za ekvivalencijom među formama koju traži istovremeno na svim razinama sustava društvene zbilje koja se proučava, Levine ne samo da gubi iz vida bilo kakvu mogućnost teoretizacije cjeline i barem relativno stabilne/konkretne logike odnosa među njenim dijelovima, već si u fiksaciji na apstraktni koncept forme kao analitičke kategorije dozvoljava da svaki uzorak, paralelizam, kôd, uočen u društvenoj zbilji, proglasi formom, tj. prema vlastitoj definiciji, pripiše mu status objekta koji autonomno (pa onda gotovo i posve slučajno) u toj zbilji proizvodi političke učinke. Svaki takav uočeni uzorak onda ravnopravno stoji u mogućoj interakciji s ostalima, a ovakva se fragmentarna formalistička analiza nastavlja u nedogled ne nudeći nikakvu relativno fiksnu i metodološki dosljednu eksplanatornu matricu. Svatko je slobodan odabrati si koje forme ga zanimaju i od njihovog

05 Prijevod moj, kao i u slučaju ostalih tekstova koji nisu dostupni na hrvatskom. 
teorijskog supostavljanja očekivati onda određene spoznajne (pa implicitno i društvenopolitičke) efekte. Od strukturalizma dominantnog polovicom dvadesetog stoljeća ova se metoda razlikuje utoliko što je posve horizontalna: svojom teorijskom misijom ne smatra, kao nekoć strukturalizam, pronalazak dubinskih strukturnih univerzalija ogoljenih od "mesa" lokalnog konteksta. Umjesto toga, pounutrivši lekcije poststrukturalizma, Levine ne pristaje na "potragu za izvorištem" već forme promatra u horizontalnim igrama, sudarima, supostavljanjima i iz rezultata njihovih fluktuacija provodi analizu lokalne distribucije političke moći. Promjena svijeta koju zaziva, događa se onda strategijom minimalnih pomaka, korak po korak, analizom i reorganizacijom jedne po jedne forme. Njen koncept forme služi pritom kao konkretan metodološki alat, nosilac političkog procesa, te prikladan legitimacijski odgovor na pitanje: što radi i čemu uopće služi humanistika?

\section{Forma - povratak na sigurno}

Nije ni čudo, dakle, s obzirom na reaktivnu prirodu, reduktivni determinizam i nespremnost da se misli cjelina društvenih odnosa, koji se pojavljuju kao refreni unutar neoformalističkog pokreta, da ga je Lesjak dodatno karakterizirala i kao pojavu "novog disciplinarnog konzervativizma” (Lesjak 2013: 17). Konzervativizam, naravno, proizlazi i iz činjenice da se navedeni pokušaji povratka problemima materijalnosti, ontološkog statusa te granica objekata proučavanja humanističkih disciplina, događaju ponajviše deklarativno, kroz pozive na reaktualizaciju starih rasprava. Kao što je primijetila Marjorie Levinson, neoformalizam prvenstveno problematizira "prestiž i praksu" humanističkih disciplina, a ne "fundamentalna načela" te u literaturi nije moguće pronaći pokušaje "reteoretizacije umjetnosti, kulture, znanja, vrijednosti, pa čak - iznenađujuće - ni forme” (Levinson 2007: 561). Ovu krizu teorijske imaginacije analizirao je Mathias Nilges u članku Marxism and Form Now ustvrdivši kako postoji "logička kongruencija između onih koji zagovaraju povratak regulaciji kapitalizma [kejnzijanizmu] u vremenima slobodnotržišnog kaosa i onih koji zagovaraju povratak tradicionalnim, stabilnim disciplinarnim strukturama u periodu nestabilnosti uzrokovane interdisciplinarnošću" (Nilges 2009: 75). Misaona struktura koja kao rješenje krize u humanistici nudi povratak na čvrsti teren starog, na "formu kakva je nekoć bila”, ovisi o mitu o autonomiji disciplinarnog identiteta i stabilnosti (možda je bolje reći "ustabiljivosti”) kako zlatnog doba humanističke proizvodnje znanja tako i modusa regulacije kapitalizma karakterističnog za period for- 
dizma koji je nekoć osiguravao i institucije potrebne za organizaciju i reprodukciju akademskog polja. $U$ zaziv za povratkom formi, dakle, istovremeno je nužno upisan i zagovor povratka izgubljenih klasnih privilegija za segmente profesionalne-menadžerske klase kojoj pripadaju i sveučilišni profesori humanistike.

No ovu formulu potrebno je nadopuniti još jednom opaskom. Nostalgični povratak mirnijim vremenima, naravno, nije zadovoljavajući odgovor na opisanu destabilizaciju humanističkog okvira regulacije proizvodnje znanja. On je nezadovoljavajuć, kao što podsjeća Nilges, zato što je iz dosljedne dijalektičke i materijalističke vizure povratak na stare historijske pozicije u novom kontekstu naprosto nemoguć. No takav je i zbog toga što je unaprijed baziran na određenoj spremnosti na kapitulaciju. $U$ eri realne supsumcije, da upotrijebimo taj koncept, akademskog polja pod kapital ${ }^{06}$, proizvodnja znanja legitimira se kao proizvodnja rezultata istraživanja, odnosno regulira se prema kvantitativnim kriterijima objektiviranim u kompetitivnom sustavu evaluacije učinkovitosti i instrumentalne upotrebljivosti tih rezultata. U takvom sustavu od bilo kakve istraživačke paradigme zahtijeva se ipak i određeni empirizam, odnosno koliko-toliko opipljiv objekt proučavanja kao i spekulativni oprez ograničen, po mogućnosti, i nekom dosljednom metodom provjere. Utoliko je i povratak formi, bila ona zamišljena naprosto kao "ono opipljivo" ili "ono instinktivno lijepo”, i implicitni pokušaj odgovora na institucionalne zahtjeve ovako uspostavljenog sustava. Nije moguće prešutjeti da je sam po sebi ovakav zahtjev za samokontrolom humanistici itekako dobrodošao. Ali unutar komercijaliziranog sustava proizvodnje znanja, on često ne garantira samo potreban minimum znanstvene uračunljivosti, već zahtijeva i "proizvodnju po narudžbi”. Drugim riječima, u sustavu novog, korporativnog sveučilišta sve je izraženija tendencija da se proizvodi samo ono znanje koje je iz perspektive sustava unaprijed označeno kao poželjno. Kao što navodi Lesjak, disciplinarni manevar kojim se pristaje na pragmatiku smjernog odgovora na takve ideološke zahtjeve regulatornog sustava i kapitalističkog tržišta pomalo je očajnički pokušaj da se "spase radna mjesta na humanističkim odsjecima u (ciničnom) prihvaćanju instrumentalizacije znanja i misli koja

06 Literatura o ovoj temi vrlo je opsežna. Iz historijsko-materijalističke perspektive, ako široko shvatimo taj pojam, o njoj su pisali Callinicos 2006, Krašovec 2011, Roggero 2011, Slaughter i Rhoades 2004. Koristan pregled polja "kritičkih studija sveučilišta" u njegovim raznim permutacijama nudi Szadkowski 2013. 
upravo i pokreće obrazovne i sveučilišne politike koje humanistiku doživljavaju kao isluženu” (Lesjak 2013: 20).

Povratak formalizmu u ovakvom američkom kontekstu još je upadljiviji i utoliko vredniji spomena i zbog toga što je prethodno gotovo u potpunosti eliminiran iz metodološkog repertoara humanistike nakon nekoliko desetljeća dominacije s početkom u tridesetim godinama dvadesetog stoljeća. No, kao što smo spomenuli na početku, ova promjena motivirana je širim institucionalnim transformacijama i ne bi je trebalo promatrati kao lokalni fenomen ograničen društvenom dinamikom nacionalnog akademskog polja i njegove specifične povijesne situacije. I postsocijalistička (polu)periferija na kojoj je locirana domaća humanistika stoji u nužnom odnosu prema istim širim institucionalnim transformacijama pa je zbog toga za materijalističku povijest kulturne proizvodnje ne samo povijesno opravdano, već i nužno uočiti postoji li analogna ili barem iole usporediva dinamika diseminacije i rekonfiguracije analognih koncepata u domaćoj humanistici. Pritom pitanja vezana uz to ne postavljamo isključivo radi utvrđivanja povijesti samih tih koncepata, već moramo imati na umu da je konkretan skup problema koji se uz njih vežu i propituju — kao što su oni autonomije kulturne proizvodnje, epistemološkog statusa kulturne teorije, stabilnosti njenih metoda te suverenosti objekta proučavanja - u svom krajnjem horizontu uvijek blisko vezan uz pitanja o strukturi specifičnog aranžmana proizvodnje znanja i strukturi društva unutar kojeg se taj aranžman realizira.

Iz te se perspektive upravo sudbina formalističke metode u domaćoj humanistici pokazuje kao zanimljiv problem koji zahtijeva pozornost jer se upravo oko njega kristaliziraju neki od osnovnih društvenih prijepora u periodu druge polovice dvadesetog i početka 21. stoljeća, odnosno u periodu od razvitka jugoslavenskog samoupravnog socijalizma preko njegovog raspada i tranzicije u (polu)periferni kapitalizam. Ovdje mi je namjera ponuditi okvir za daljnju teorijsku razradu tog problema i uputiti na nekoliko zapostavljanih proturječja domaće humanistike u nadi da bi tako postavljena šira slika možda mogla poslužiti ne samo kao nacrt kritike humanističkih tradicija o kojima je riječ, već i kao oslonac za promišljanje njihove buduće uloge i razvoja.

\section{Formalizam na periferiji: dugo trajanje}

Diskusija o formalizmu u domaćoj humanistici, odnosno književnoj znanosti, velikim je dijelom diskusija o tradiciji Zagrebačke stilističke ili Zagrebačke književnoznanstvene škole, inicijalno zasnovane kroz 
rad ljudi kao što su Aleksandar Flaker, Zdenko Škreb i Ivo Frangeš u pedesetim godinama dvadesetog stoljeća. Zagrebačka škola presudno je obilježena recepcijom ruskog formalizma kao i recepcijom njemačke stilističke kritike ${ }^{07}$, a kao pokušaj razvitka nove i suvremene metode ${ }^{08}$ proučavanja književnosti uspostavila se kroz dvojaku opoziciju: prvo kroz opoziciju pozitivizmu i biografizmu nacionalno-filoloških pristupa koji dominiraju od kraja 19. stoljeća do Drugog svjetskog rata, a onda i kroz opoziciju kratkom poslijeratnom periodu u kojem je ekonomski redukcionizam teorije odraza, prema uzoru na tendencije prisutne u Sovjetskom Savezu, dobio na značenju kao univerzalna eksplanatorna matrica. Prema Davoru Dukiću, projekt Zagrebačke škole u njegovoj prvoj fazi može se sažeti u šest temeljnih postavki, a osim već spomenutog oslonca u njemačkoj stilističkoj kritici i teoriji interpretacije te ruskom formalizmu, to su: potreba za razvitkom autonomnih metoda znanosti o književnosti i jasnih definicija njenog objekta proučavanja; koncepcija književnog teksta kao izdvojenog iz društvenopovijesnog konteksta i odvojenog od biografije autora kao "polazište i cilj književnoznanstvene analize"; književni tekst kao umjetničko djelo, odnosno ontološki status književnog teksta je onaj estetskog objekta, on je "relativno autonomna duhovna djelatnost", a ne "odraz svjetonazora, ideologije ili odnosa u ekonomskoj proizvodnji” te se taj njegov status može objektivno, znanstveno vrednovati; analitički fokus škole na kategoriju stila, odnosno na analizu formalnih književnih postupaka; i na kraju, "ključna književnoznanstvena metoda [jest] stilistička interpretacija nekog kanonskog književnog teksta" (Dukić 2009: 140-3). Osnovni bi se credo škole u svojoj prvoj fazi, dakle, mogao sažeti kroz postmodernom uhu svakako prejaku, možda i pomalo bizarno samouvjerenu, tvrdnju Zdenka Škreba (odnosno Wolfganga Keysera s kojim se Škreb slaže u svojem članku) o tome kako "centar znanosti o literaturi [treba da bude] znanstveno egzaktna umjetnička interpretacija književnog djela” (Škreb 1998: 33). Radi se dakle o pokušaju, usporedivom s ostalim formalističkim pokušajima iz prve polovice dvadesetog stoljeća, kao što je uz ruski for-

07 O povijesti ideja i utjecaja Zagrebačke škole vidi Užarević 1995, 2015, Dukić 1995, Udier 2011.

08 Nije posve moguće heterogene pristupe autora Zagrebačke škole, pogotovo u kasnijim fazama, obuhvatiti pod kišobranom jedinstvenog projekta, ali neka slaganja, primjerice oko autonomnog statusa književnosti kao objekta proučavanja, svakako postoje, što navode Oraić Tolić 2004 i 2009, Užarević 1995, i drugi. 
malizam primjerice i američka Nova kritika, da se izgradi sistematična i autonomna tehnika proizvodnje znanja o "umjetnosti riječi”, tj. da se izgradi znanost o književnosti, bazirana na univerzalnim kategorijama i konceptualnom aparatu adekvatnom autonomnom statusu samog predmeta pročavanja te "profinjenim, a znanstveno egzaktnim metodama” (ibid.). Ova "znanost estetike" i pripadajuća joj koncepcija estetskog objekta kao rezultata djelovanja autonomnih zakona proširena je u slučaju Zagrebačke škole i koncepcijom znanstvenosti interpretacije pa je tako disciplinarna kontrola nad objektom proučavanja u potpunosti uspostavljena. U kontekstu socijalističke države blagostanja i njenih akademskih institucija, pružila se pritom i prilika za izgradnju institucionalnog okvira u kojem bi se proizvodio znanstveni diskurs koji bi legitimirao i reproducirao ovakav književnoznanstveni model kroz duži period.

Ovako postavljen projekt, kao što je uostalom i dobro poznato, otpočetka se morao suočiti s brojnim problemima. Od činjenice da unutar same škole nije bilo jedinstvene koncepcije i jedinstvenih rješenja za teorijske nedoumice koje su se pojavljivale pa do neprestane autorefleksije o elementarnim pojmovima, misiji, i uopće epistemološkom temelju ovakvog projekta. Ako se prati sam njegov kasniji razvoj unutar akademskog polja, moguće je ugrubo ustvrditi da u kasnijim fazama, tijekom šezdesetih i sedamdesetih, pa konačno i osamdesetih godina dvadesetog stoljeća, dolazi do dva osnovna pomaka u odnosu na prvotno zacrtani projekt. Najprije je, kako piše Davor Dukić, relativizirana privilegirana pozicija književnosti i njen status svojevrsne ultimativne kulturne forme, a u polje interesa znanosti o književnosti počinje se uvoditi koncept kulture kao šire antropološke reference (2009: 137) ${ }^{09}$. Nakon toga je krajem osamdesetih godina provedeno i temeljitije teorijsko i kritičko preispitivanje metafizike znanosti o književnosti pod utjecajem recepcije poststrukturalizma te

09 Dukić 2009 navodi da je “pravi antropološki zaokret” nastupio tek s početkom 21. stoljeća s objavljivanjem radova poput Pojmovnika suvremene književne i kulturne teorije Vladimira Bitija, Kulturalni studiji: ishodišta i problemi, Deana Dude, ili Novog historizma: poetika kulture i ideologija drame Davida Šporera. Taj “pravi antropološki zaokret” možda označava trenutak u kojem kulturološka paradigma postaje dominantna, odnosno dovršetak njene recepcije, no ozbiljnije okretanje od formalizma/imanentizma Zagrebačke škole pokrenuto je ranije, možda najupadljivije temeljitim preispitivanjem njenih postavki u osamdesetim godinama, za što je najzaslužniji V. Biti. 
su u pitanje dovedene kako njene epistemološke pretpostavke, tako i kasniji iz toga proizašli pokušaji razrade "imanentnih" historiografija književnosti ${ }^{10}$. Upravo je koncept "imanentizma", ${ }^{11}$ odnosno tvrdnja da se književnost razvija, a znanost o književnosti konstituira otkrićem i formalizacijom autonomnih zakona "literarnosti" imanentnih proučavanom korpusu, u današnjem kontekstu nositelj kritički negativnog naboja koji su proizvela kasnija kritička promišljanja nasljeđa Zagrebačke škole.

Već iz ovakve skice može se vidjeti da dinamika formacije i dekonstrukcije projek(a)ta Zagrebačke škole odgovara široj dinamici razvoja humanistike, ili barem književne teorije i kulturnih studija, u drugoj polovici dvadesetog stoljeća na Zapadu, dinamici koja je potkraj stoljeća značila napuštanje univerzalističkih znanstvenih aspiracija i okretanje dekonstrukciji, kritici ideologije i teoriji diskursa kroz koje su propitane ne samo autonomaške koncepcije čvrstog razgraničenja književnosti/kulturne forme od njenih društvenih okolnosti, već $i$ iluzije o razvoju te forme uvjetovanom imanentnim zakonima.

Pokušaji opisa ovakvog razvoja u domaćem kontekstu često rezultiraju povijesnim narativima s određenim teleološkim implikacijama ${ }^{12}$. (Ako to i nije njihova primarna intencija, moguće je da je teleologija naprosto učinak kronološke ekspozicije koju ne nadopunjava adekvatna historijsko-materijalistička analiza i vezivanje uz kompleksniji povijesni sadržaj.) Sazrijevanje i realizacija kasnijih kritika Zagrebačke

10 U ranijem radu Dukić navodi kako književne historičare Zagrebačke škole karakterizira "načelno nepristajanje na strogo imanentnu povijest književnosti" (1995: 54). Naglasak bi ovdje trebao biti na "strogo", budući da Biti u svojim kritičkim studijama (Biti 1989) pokazuje kako se historiografske paradigme Zagrebačke škole uvelike oslanjaju na imanentizam.

11 Prema Dukić 2009, termin imanentizam uvela je Dubravka Oraić Tolić (cf. Oraić Tolić 2004). U periodu aktivnosti Zagrebačke škole, koristio se termin "unutrašnji pristup" kao prijevod engleskog termina intrinsic approach pa je pod tim terminom Svetozar Petrović poduzeo i njegovu prvu "sustavnu analizu i kritiku [...] a time implicitno i kritiku Zagrebačke škole” (Dukić 2009: 140). Ovdje ćemo termin imanentizam često koristiti u kombinaciji s terminom formalizam budući da se odnose na istu misaonu paradigmu, pri čemu imanentizam ima nešto tehnički uže značenje i odnosi se na specifičnu koncepciju razvoja forme iz unutrašnjih zakona.

12 Ovo je posebno vidljivo kod D. Oraić Tolić 2004, 2009 o čemu će u ovom tekstu riječi biti nešto niže. 
škole iz tih narativa izlazi s aurom svojevrsnog dostignuća, a Zagrebačka škola s onom prevladane naivne faze. No uz ovakvu teleologiju prelako je zaboraviti na nekoliko društveno značajnih detalja: najprije činjenicu da središnji znanstveni časopis koji je škola ustanovila 1957. godine, Umjetnost riječi, izlazi i danas te je i dalje dosljedno specijaliziran za umjetnost riječi, kao i uvelike orijentiran na probleme književne stilistike i interpretacije (bez obzira na nedavna proširenja fokusa prema kazalištu i filmu te već dugotrajnu otvorenost za radove koje se ne može svrstati u tradicionalnu paradigmu). Uz to, specifične kategorije i skolastički dometi ranijih faza Zagrebačke škole izuzetno su bitni i državnim ideološkim aparatima, budući da su temeljito integrirani u kurikulum nastave jezika i književnosti na svim obrazovnim razinama $^{13}$. Iz toga je moguće zaključiti da je kritička obrada postavki Zagrebačke škole bila bez snažnijih učinaka na širem društvenom planu, bez obzira na određene transformacije akademskog diskursa koje su njome motivirane. Na kraju, znatno teže uočljiva i u okviru ovog teksta puno zanimljivija, jest i činjenica da, ako i jest moguće promatrati određeno rastakanje idealističkih koncepata Zagrebačke škole na putu od književnosti do kulture, estetskog objekta do diskursa, ili ponajviše kroz kritiku imanentizma, to ne znači da ti koncepti potpuno nestaju iz konceptualnog aparata humanističkog mišljenja čak i u najtemeljitijih njegovih kritičara. Umjesto toga, moguće je primijetiti da se "unutrašnji pristup", "imanentizam” izmještanjem na drugi teren nanovo aktivira s novom svrhom. Uzimajući u obzir usmjerenost kritike Zagrebačke škole upravo na njen formalizam/ imanentizam, ovo nemalo iznenađuje. No utoliko je lakše zapaziti nesumnjivo ideološku motivaciju takvog izmještanja, kao i analizirati njegove političke efekte. Kako bih objasnio na što konkretno mislim, odnosno kako bih ilustrirao da formalizam Zagrebačke škole njegovi mlađi baštinici i kritičari u novim kontekstima ne napuštaju, već

13 Josip Užarević navodi kako je "[Zagrebačka škola] preda se od početka postavljala i svojevrsnu prosvjetiteljsko-pedagogijsku zadaću: znanosti o književnosti trebalo je osigurati autonomiju, tj. izvršiti njezinu institucionalizaciju i uklapanje u sustav akademskoga obrazovanja, ali ju je isto tako trebalo "prilagoditi" podučavanju književnosti na razini osnovnih i srednjih škola. Odatle Škrebova težnja za izgradnjom i usustavljivanjem književnoznanstvene terminologije, odatle opća potraga za interpretacijskim modelima koji bi bili razumljivi djeci i laicima; a istom se težnjom donekle može objasniti sklonost deskriptivnosti i svojevrsnu znanstveno-organizacijskomu administriranju" (Užarević 2015: 518). 
reproduciraju na drugoj razini, koncentrirat ću se na tekstove dvoje autora koji su ovim temama posvetili podosta pažnje.

\section{Dubravka Oraić Tolić: estetika forme nacije}

U nizu tekstova o formaciji i razvoju Zagrebačke škole, Dubravka Oraić Tolić njen historijat ispisuje s određenom vrstom benevolentne nostalgije te o znanstvenom projektu škole govori u prošlom svršenom vremenu. Škola je tako bila "vrhunac i kraj paradigme imanentizma" (2004: 21), te je "svečano otpraćena u povijest ostavivši iza sebe bogatu baštinu” (2009: 191). Tu bogatu baštinu Oraić Tolić smješta u kontekst šire dvadesetostoljetne teorijske dinamike koja od ruskog formalizma, preko strukturalizma i semiotike, pa poststrukturalizma, vodi do novohistorističke analize diskursa i kulturnih studija. Oraić Tolić tu dinamiku sažima u formuli "od imanentizma prema kulturologiji” (ibid. 181), odnosno ustvrđuje da je ideja kulture na kraju 20. i početku 21. stoljeća "dio epistemološkog obrata od esencijalizma prema konstruktivizmu” (ibid.), da suvremena kulturologija, koja je prevalila put od jednog do drugog od ova dva pola, više ne traga bilo za metafizičkim statusom, bilo za "klasnim temeljima" ili bilo kojom drugom vrstom krajnjeg uzroka svog objekta proučavanja, jednako kao što kulturna proizvodnja više nije podvrgnuta procesima kanonizacije, a sama "ideja kulture više nema vrijednosni predznak" (ibid. 188-9). Umjesto toga, "suvremena se kulturologija pita” o ideološkoj motivaciji i funkciji kulturne proizvodnje i "konstrukciji mentaliteta i identiteta, rodnih, rasnih i civilizacijskih razlika" te se vraća historizmu 19. stoljeća, kulturne filozofije i Frankfurtske škole, ali ovaj puta "bez vjere u neutralnost činjenica", "duha vremena" ili "vjere u eshatološki ishod povijesti” (ibid. 189).

Ako ostavimo po strani probleme s historiografski široko i terminološki labavo postavljenim okvirom, potrebno je uočiti teleološki oslonac ovakve historizacije, odnosno narativ o zlatnom dobu, kraju, i novom dobu koji na svom završetku, kao dostignuće, uspostavlja postmoderni novohistoristički socijalni konstruktivizam (pri čemu, da spomenemo, u ovom narativu nedostaje ikakav zadovoljavajući osvrt na historijsku motivaciju ovakvog razvoja). Naravno, upravo bi s pozicije koja prihvaća dosege kritike filozofijske metafizike i osjetljiva je na uvide socijalnog konstruktivizma i kritike ideologije - kakva je deklarativno pozicija Oraić Tolić - ovako koncipiran historijat trebao biti izuzetno problematičan. No autorica ovdje to ne samo da ne uočava, već taj historijat dodatno razvija upravo u otklonu od svog 
nominalnog teorijskog okvira. On postaje još zanimljiviji kad mu se pridodaju organske i biološke metafore kojima se Oraić Tolić služi kako bi opisala razvitak Zagrebačke škole. Tako njene razvojne faze postaju "gledano u biološkom ključu [...] doba" (ibid. 190), a generacije autora koji se uz taj razvoj vezuju dijele se na "očeve”, "braću” i "djecu” (2004: 21). Nije teško zaključiti kako takav retorički postupak ima funkciju da povijesti ovog utjecajnog projekta domaće humanistike prida obilježja neke vrste cehovskog mita. Pritom možda i nije neobično da iskušenju mitopoieze podlegne autorica čiji je individualni razvoj usko vezan uz intelektualnu dinamiku i institucionalnu konfiguraciju Zagrebačke škole. No intencija ove mitopoieze u svojim ambicijama itekako nadilazi puku privatnu ili cehovsku lokalnost i postaje jasna tek kad se zamijete opetovane usputne opaske o "stvarnoj" motivaciji za intelektualni projekt Zagrebačke škole. Ta je motivacija, prema Oraić Tolić, eksplicitno politička:

Paradigma imanentizma našla je pogodno tlo u glavnome hrvatskom gradu zbog specifičnih stručnih i ideoloških razloga. Stručni su razlozi bili nepostojanje izgrađene književnoznanstvene discipline na domaćem terenu [...]. Skriveni $\left(\right.$ sic $\left.^{14}\right)$ su razlozi nastanka škole bili snažna, javno neizrečena volja da se preko moderne književnoznanstvene discipline riješe brojna identitetska pitanja iz nacionalnog jezika i kulture [...] Paradigma imanentizma bila je idealan 'kišobran' da se takva škakljiva pitanja postavljaju i rješavaju bez opasnosti da se u sve to umiješa službena, tada još uvijek snažna, komunistička ideologija. (2009: 189)

Što točno znači "rješavanje identitetskih pitanja iz nacionalnog jezika i kulure” postaje jasnije iz ranijeg teksta u kojem Oraić Tolić ponovno tvrdi da je ne samo Zagrebačka škola, već konkretnije i puno dalekosežnije, sam obrat ka "imanentnom pristupu tekstu” nastao iz potrebe "da se nađe područje na kojemu će se u centralističkoj višenacionalnoj zajednici, kakva je tada bila Jugoslavija, neometano njegovati nacionalni identitet, ponekad i pod maskom znanstvene neutralnosti” (2004: 23). Prema Oraić Tolić, dakle, formalizam/imanentizam Zagrebačke škole, daleko od toga da bi bio pokušaj uspostave autonomne znanstveno-disciplinarne paradigme, heteronoman je projekt stvaranja en-

14 Teško je oteti se dojmu da je ova kategorijalna omaška, zamjena najavljene kategorije "ideološki" onom "skriveni”, simptom upravo slabo skrivenih ideoloških motivacija same Oraić Tolić. 
klave u kojoj bi se izvan političkog nadzora u kontroliranim uvjetima proizvodila nacionalistička ideologija.

Ova tvrdnja, dakako, izuzetno je problematična. Ne samo zbog toga što je nakon čak i usputnog kritičkog preispitivanja teorijski nekonzistentna ${ }^{15}$, već i zbog toga što ako već želimo autonomašku koncepciju Zagrebačke škole i njen institucionalni aranžman povezati s nekom vrstom strukturnog ekvivalenta, taj nećemo pronaći u defanzivnoj projekciji etnonacionalne zajednice kakvu sugerira Oraić Tolić, već upravo u postojećem konceptu samoupravne radne zajednice, odnosno sistemu samoupravljanja jugoslavenske socijalističke države i njenih institucija.

No pustimo na stranu historiografsku instrumentalizaciju projekta Zagrebačke škole u ime nacionalističke ideološke agende — od nje je puno zanimljivija teorijska instrumentalizacija formalističkih koncepata škole $\mathrm{u}$ to isto ime. Tražeći oslonac u terminima postmoderne kulturologije, u knjizi Muška moderna, ženska postmoderna iz 2005. godine, Oraić Tolić krvavi raspad Jugoslavije objašnjava kulturološki: uzroke mu traži u pretpostavljenom formalnom/imanentnom imperativu da se moderni nacionalni identiteti realiziraju u modernoj formi, odnosno naciji-državi. Drugim riječima, "moderna nacionalna povijest" pojedinih nacija koja "nije u bivšoj Jugoslaviji bila dovršena" (2005: 272) naprosto se mora u cjelini dovršiti; nije je, kao neko uobičajeno potisnuto, moguće sublimirati niti pretvoriti u simptom. Kao

15 Npr. kako u okviru lokalne političke dinamike koji nudi Oraić Tolić objasniti međunarodnu rasprostranjenost srodnih formalističkih paradigmi? Zašto se one javljaju, s istim autonomističkim zahtjevima, i u kontekstima u kojima nacionalno pitanje nije akutno? Isto tako, kako unutar navodne determiniranosti Zagrebačke škole potrebom za proizvodnjom nacionalističke ideologije objasniti njen teorijski razvoj ka transnacionalnim historiografijama književnosti i transnacionalnim konceptima kao što su Flakerove "stilske formacije"? Na kraju, ako se u obzir uzme i internacionalistička usmjerenost ugrađena u historijsku intenciju same znanstvene racionalnosti nekih od začetnika i nositelja ruskog formalističkog mišljenja (npr. R. Jakobson) koje je presudno utjecalo na Zagrebačku školu, možemo zaključiti da postulacija ovakvog paralelizma između formalističkih koncepata i etnonacionalne autarkije predstavlja ne samo teorijsku nekonzistentnost, već i grubu krivotvorinu. O Jakobsonovoj kritici genetičkog historizma te slavenskog etničkog $\mathrm{i}$ jezičnog identiteta na pretpostavkama ruskog formalizma $\mathrm{i}$ strukturalističkog mišljenja u njegovim političkim spisima iz tridesetih godina dvadesetog stoljeća, može se, u kontekstu raspada Jugoslavije devedesetih godina, naći u Mikulić 1993. 
naprasno prekinuta priča, ona smeta, traži da se ispriča do kraja, te realizira u svojoj cjelovitosti: "Na mitskome Balkanu velika metapriča o modernoj naciji nije bila ispričana do kraja, nego više puta zapetljavana i raspetljavana” (ibid.). Takvi neispričani, nerealizirani nacionalni identiteti, budući da su pod formalnim imperativom realizacije, $u$ zadnjem času moderne realiziraju se nasilno i brišu granicu između "fikcije i zbilje, između epskih hajduka i postkomunističkog naroda, između politike i poetike. ... [stoga je] nedovršena povijest s početka moderne kulture”, poetički se izražava Oraić Tolić, "zaplesala svoj posljednji ratni ples” (ibid. 281). Pa se tako, u krvavoj kulturološkoj nužnosti, raspala Jugoslavija.

Ako stavimo na stranu činjenicu da je ovo tumačenje izrazito upitne eksplanatorne vrijednosti, odnosno ako stavimo na stranu to da je ideološko i bez pretenzija na minimum historijske provjerljivosti i teorijske (kulturološke, sociološke, političko-ekonomske) preciznosti, izuzetno je zanimljivo to što se njime jedan kompleks povijesnih događaja ne samo radikalno estetizira, već i tumači formalistički, zakonima imanentne dinamike forme čije se hipostaziranje s kulturoloških pozicija, koje zastupa Oraić Tolić, spočitava ranijoj socijalističkoj znanosti o književnosti: "nedovršena povijest" prema Oraić Tolić nema izbora nego da se odvrti do kraja, sadržaj modernog nacionalnog identiteta mora se ostvariti u svojoj odgovarajućoj modernoj formi, državi. No pošto je zakasnila, i postmoderna već kuca na vrata, tamo će joj osnovna zadaća biti, završava Oraić Tolić analizu, kulturna briga o nacionalnom identitetu: "mali narodi kojima je bilo teško postići slobodu i stvoriti nacionalnu državu” (ibid. 282) u postmodernom globaliziranom dobu

imat će identitet u tolikoj mjeri u kojoj će raspolagati svijetom simbola. U jedinstvenome političkom i gospodarskom prostoru, kada su proizvodi, vrijednosti i ponašanja opći, jedini jamac posebnosti i identiteta bit će simbolični prostor: vlasništvo nad imaginacijom - jezik, ime, etikete. (ibid. 282)

Kao što je to uvijek slučaj s isuviše reduktivnim objašnjenjima kompleksnih društvenopovijesnih fenomena, upravo je njihova elegancija istodobno i mjera njihove vulgarnosti. Oraić Tolić vidi postmoderni, socijalno-konstruktivistički relativizam kulturologije kao dozvolu, kao alat koji nacional-humanistika može iskoristiti da pomogne naciji u njenom identitetskom samoostvarivanju unutar globalnog tržišta. Jer to i jest jedino što je ovoj perifernoj naciji u kapitalističkoj univer- 
zalnosti iz strukturnih razloga preostalo-komodifikacija nacionalnog identiteta, odnosno turizam. No pravo epistemološko pitanje je, naravno, koliko je ovakva vizija humanistike rezultat proizvoljnosti i idiosinkratičnih teorijskih kontradikcija Oraić Tolić, a koliko naprosto osvajanje prostora otvorenog relativizmom postmodernog identitetskog socijalnog konstruktivizma. Drugim riječima, je li unutar te paradigme zaista dovoljno da se kaže 'identitet i kultura' pa da, prema Feyerabendovoj krilatici, doista sve može proći, uključujući i visokoideologizirane spekulacije te fantazme o identitetskim razlikama koja ne podliježu kriterijima minimalne znanstvene, materijalističke samokontrole?

\section{Vladimir Biti: nužna forma identitetske ekspresije}

Na gornje pitanje možda možemo ponuditi implicitan odgovor ako pogledamo kako se prema pitanju identiteta iz teorijski znatno dosljednije pozicije odnosi vjerojatno najtemeljitiji postmoderni kritičar epistemoloških okvira domaće književne znanosti, Vladimir Biti.

U nizu studija s kraja osamdesetih i početka devedesetih godina, Biti sistematično kritički razgrađuje dvadesetostoljetnu tradiciju domaće znanosti o književnosti i književne historiografije. Integriravši pomalo eklektički uvide teorijskih rasprava iz konteksta francuskog poststrukturalizma (poput Althusserove teoretizacije ideologije i Foucaultove analize diskursa), njemačke estetike recepcije (čitatelj kao lokus proizvodnje značenja kod Jaussa i Isera), dijaloške filozofije Mihaila Bahtina te marksističke teorije (česta referenca je althusserijanski marksizam ranog Terrya Eagletona), Biti temeljitoj kritici podvrgava epistemološke pretpostavke i teorijsku aparaturu koju je izgradila domaća teorijska proizvodnja u sklopu Zagrebačke škole. Ako bi se ova kompleksna kritička intencija pokušala sažeti, moglo bi se reći da Bitijev kritički projekt određuju tri osnovne teorijske preokupacije. Od toga su prve dvije negativne, odnosno radi se o kritikama ograničenja formalističkih ili metafizičkih koncepcija drugih autora, a treća je pozitivna, odnosno radi se o sugestiji alternativnog teorijskog pristupa. Ili još konkretnije, u slučaju prve preokupacije radi se o historističkoj kritici metafizičke dominante u domaćoj književnoj historiografiji:

Pokušat ću dakle slijediti teorijske tekstove o kojima govorim do one nesvjesne razine na kojoj njihovo razumijevanje književnosti prestaje 'biti u stanju znati sebe', tako da način kojim mu se književnost nadaje u konkretnom povijesnom trenutku spontano teorijski promovira u njezinu natpovijesnu kvalitetu. (Biti 1989: 132) 
U slučaju druge, radi se o kritici književnih teorija koje ističu "estetsku funkciju kao dominantu književne umjetnosti” (ibid. 135) i negiraju njenu uronjenost u mrežu ideologiziranih diskursa te konkretne društvenopovijesne odnose. U ovom se slučaju zapravo radi o kritici formalističke koncepcije književnosti, a spominjući praškog strukturalista Mukařovskog te posebno doajena Zagrebačke škole Aleksandra Flakera, Biti piše sljedeće:

Dok vraćaju književnom djelu pomalo izgubljenu kantovsku svjedodžbu 'svršnosti bez svrhe' ti se 'dogmatici forme', kako ih je nazvao David Carroll, očituju dužnicima jednog povijesno ograničenog i u međuvremenu izjalovljenoga samorazumijevanja književnosti kao dokidatelja funkcionaliziranih odnosa u svijetu života. (ibid. 136)

Za dogmatike forme, nastavlja Biti, odnos između estetskog potencijala teksta i konkretnog čitateljevog iskustva čitanja odnos je identiteta. Ili konkretnije, inzistiranje (Flakerovo i Škrebovo) na "književnom tekstu kao polazištu književnoznanstvene analize” (ibid.), valja shvatiti u svjetlu opaske Renea Welleka o tome kako za formaliste tekst nije samo uzrok poetskog iskustva čitatelja, već je čitateljevo iskustvo upravo iskustvo teksta - u tom odnosu i formaciji "poetskog iskustva" izvantekstualni faktori i ne igraju neku ulogu.

Nakon ovako izvedene kritike, treća Bitijeva preokupacija, ona pozitivna, naznačena je u poglavlju Povijest književnosti nakon poststrukturalizma: Kriza hegelovskih modela. Ovdje Biti pledira za teorijsku vizuru u kojoj bi se s pozicije koja uključuje svijest o svojoj nužnoj partikularnoj ograničenosti prakticirala "apatija" promatrača naspram totalizacijskih aspiracija deskriptivnih projekata zaokružene povijesti književnosti (kao što su oni Viktora Žmegača, Milivoja Solara ili Aleksandra Flakera):

Ideologizacija jedne diskurzne odnosno nediskurzne prakse počinje onoga trenutka kad ona pokuša taj svoj partikularni 'spoznajni predmet' prometnuti u totalan 'stvarni'. Tada ona uzdiže svoju figuru Drugoga u opće načelo, a svoj ideal ispravnosti proglašava važećim za sve druge. Poststrukturalisti preferiraju, umjesto tako entuzijastičkog stava, zadržati svoju teorijsku vizuru u stanju koje je Freud nazvao 'ein kühles Wohlwollen', a Lyotard, slijedeći ga, 'apatijom'. Možda će taktička intervencija koja nastupa u ime trenutačno osporene i nesmještene vrijednosti biti bliža pojedinačnosti fenomena od bilo kakve generalne strategije. (ibid. 216) 
Ipak, usprkos ovoj kritičkoj trijadi te težnji za osvješćivanjem i pažljivim markiranjem ideoloških koordinata pojedinačnih iskaznih pozicija, u knjizi izašloj 1994. godine pod naslovom Upletanje nerečenog: književnost/povijest/teorija, Biti, vjerojatno pod pritiskom teških povijesnih uvjeta u periodu raspada Jugoslavije, pišući o nacionalnom identitetu i jugoslavenskim ratovima, ponešto relativizira raniji oksimoronski koncept "apatičnog angažmana" te, znatno bitnije, poistovjećuje potencijal kulturno-identitetske ekspresije i konkretno povijesno iskustvo realizacije identiteta - na jednak način na koji književni formalisti ranije shvaćaju odnos između estetskog potencijala teksta i konkretnog čitateljevog iskustva.

Kao i Oraić Tolić u svojoj desetak godina mlađoj knjizi, Biti se u Uplitanju nerečenog kreće između terena povijesti književnosti i političke povijesti, a u ključnim trenucima kao centralni objekt analize izranja nacija, odnosno koncept nacionalnog identiteta. Tako poglavlje "Posezanje za povijesti - balkanski specijalitet?" sadrži kritiku binarnih opozicija na kojima je izgrađena zapadnjačka kognitivna mapa Europe te Biti u njemu dekonstruira položaj Balkana kao njezinog drugog. No još relevantnije, poglavlje sadrži i neku vrstu teoretizacije nacionalnog identiteta kao "nagona za identifikacijom" i "nagona za prisvajanjem povijesti” (1994: 125, 132) te politike kao napetosti između nagona za autentičnom identitetskom ekspresijom prosvjetiteljskog "običnog čovjeka", "svatkovića" te intelektualca koji s njim dijeli javnu sferu i, po prosvjetiteljskom receptu, pretendira da eshatološki govori "za” svatkovića, iako bi, po Bitijevom, bilo produktivnije da "osluškuje” oslovljavajući ga pragmatično u njegovoj autentičnoj sadašnjosti:

Ako već ne političarima, onda je barem intelektualcima vrijeme za ozbiljno preispitivanje odnosa prema anonimnim masama prikraćenih. Potiskivanje njihovih legitimnih zahtjeva za identitetom moglo bi dovesti ne samo do dubokih povreda osjećaja vlastite vrijednosti i do brzog isticanja simbola solidarnosti, nego i do mnogo kobnijega samožrtvovanja u korist opojno nadmoćne cjeline. Takvom bi se fašističko-komunističkom porivu, ako nije prekasno, valjalo djelotvornije suprotstaviti, što znači strpljenjem umjesto nasiljem. (ibid. 129)

Legitimni zahtjevi za identitetom, koje upućuju "anonimne mase prikraćenih" i koje je toliko važno priznati, kulturnopovijesno između ostalog proistječu iz židovsko-grčkih "povijesnih korijena Europe" 
(ibid. 132) i u svom starom, "predznanstvenom" aspektu koji je, prema Bitijevom tumačenju, mnogo rasprostranjeniji od znanstvenog, prosvjetiteljskog, povijest shvaćaju kao "zaštitnika" te počivaju "na uvriježenim i izuzetno rezistentnim identifikacijskim i legitimacijskim mehanizmima, na urođenom nagonu za samopotvrđivanjem i potrebi za razgraničenjem" (ibid. 136).

Konkretna povijesna pozadina, a do određene mjere čak i eksplicitna motivacija Bitijevog teksta i njegovih preokupacija nacionalnim identitetom, nasilnim "prisvajanjem povijesti” te razgraničenjem, jest naravno raspad Jugoslavije i formacija postsocijalističkih etnonacionalnih država. Biti ovaj raspad tumači u ključu identitetske ekspresije, kao što to čini i Oraić Tolić, pa bez obzira na to što izbjegava njezinu reduktivnu metafiziku, ostaje neosjetljiv za historijske potencijale nevidljive iz perspektive povijesti nacije kao identitetske ekspresije, odnosno perspektive koja dinamiku te povijesti zamišlja estetički, normativno-formalistički, kao kulturni sadržaj u potrazi za realizacijom kroz odgovarajuću, ekskluzivističku formu države.

Kao što je vidljivo iz gornjih citata, identitetska ekspresija, uz koju se instinktivno vezuje i "razgraničenje", za Bitija je "urođeni nagon" i "potreba"16. Doduše, zamisao instinktivne potrebe za ekspresijom kolektivnog identiteta možda i nije previše sporna, čovjek je ipak društveno biće, no pitanje o "identitetskom instinktu" nije ključno teorijsko pitanje koje ovdje valja postaviti. Ključno je sljedeće: ako i pristanemo na to da postoji stanovit "nagon" za identitetom, to nam i dalje ne daje odgovor na pitanje koji su to povijesni uvjeti

16 Treba napomenuti da je Bitijev tekst u razradi problema identiteta zaokupljen ponajviše kolektivnim identitetom te je koncept "identitet" najčešće upotrebljavan upravo u tom, kolektivnom, značenju. No problematika individualnog identiteta i njegove kompleksnosti, inače akutna za zapadnu postmodernu misao, izranja možda pomalo iznenađujuće i više implicitno nego eksplicitno na samom kraju teksta. Pritom ostaju nerazjašnjena pitanja poput kako bi se točno odvijao prijelaz iz individualnog u kolektivno te je li završna usmjerenost teksta na individualni identitet istovremeno i sugestija da je upravo individualni identitet $u$ svojoj fluidnoj kompleksnosti taj kojim treba nadomjestiti kolektivni. Pitanje modusa tog nadomještanja - kao i je li ono uopće strukturno moguće ako već postoji "nagon" i "potreba" za kolektivnom identifikacijom - osim sugestije da bi "trijezni intelektualci" mogli imati neku ulogu u tome, također ostaje otvoreno. Što se samog koncepta "nagona" tiče, on je u tekstu korišten u relativno općenitom značenju, shvaćamo ga kao univerzalnu strukturu na razini individue koja, ako se realizira kao kolektivni identitet, može imati i kolektivnu manifestaciju. 
unutar kojih se taj nagon ima potrebu - ili nema izbora - izraziti upravo u formi nacije? Zašto je upravo etnonacionalna država forma adekvatna za historijski prijelaz iz samoupravnog socijalizma u periferni kapitalizam? Nije li se "razgraničenje" moglo obaviti i po manje ekskluzivističkom i fatalnom modelu? Biti na ovo pitanje ne samo da ne daje odgovor, već ga ni ne postavlja, odnosno materijalizaciju identitetske ekspresije u jednoj historijski uvjetovanoj formi uzima kao neizbježan i jedini mogući rezultat. Podsjetimo se na već naznačenu analogiju: kao što raniji književni formalisti koji odnos između estetskog potencijala teksta i čitateljevog iskustva shvaćaju kao odnos identiteta - estetsko iskustvo jest iskustvo teksta — tako i Biti kao formalistički čitatelj povijesti poistovjećuje potencijal kulturno-identitetske ekspresije i konkretno nacionalno-povijesno iskustvo - iskustvo identiteta jest iskustvo nacije. Pritom odgovornost za ovaj manjak teorijskog opreza i nedostatak historijske imaginacije, čiji je rezultat naturalizacija historijskog procesa uspostave etnonacionalizma kao dominantne ideologije postsocijalističkih društava, izmješta drugamo, na svatkovića, na "prosječnog građanina”, na onog kojeg taj identitet navodno toliko svrbi da se ne može suzbiti da ga izražava: "Potiskivanje njihovih legitimnih zahtjeva za identitetom moglo bi dovesti ne samo do dubokih povreda osjećaja vlastite vrijednosti i do brzog isticanja simbola solidarnosti [...] Pritom ne možemo polaziti od shvaćanja da smo mi ti koji bolje znamo što se s njima zapravo događa” (ibid. 129).

Pa kad se taj identitet već mora izraziti, onda je barem potrebno da se izrazi kontrolirano, "trijezno", kako se ne bi dogodio povratak potisnutog u nekoj povijesno zlokobnijoj formi:

Stoga ne treba oslovljavati neizvjesnoga adresata koji će jednom u budućnosti biti jedinstven, nego onoga koji sada očajava, koji trpi pod pritiskom političkih, socijalnih, ekonomskih i drugih antagonizama i istodobno nastanjuje različite, protuslovne povijesti. Ono što nam je danas nužno potrebno jesu dakle fina, ali životno važna razlučivanja. Čini se da bismo ih mogli očekivati jedino od trijeznih, prozaično pragmatično usmjerenih, takozvanih specifičnih intelektualaca usidrenih u svijetu života. (ibid. 139)

Trijezni, pragmatično usmjereni intelektualci oni su dakle, koji osluškuju odjeke iz "svijeta života" otkud dolaze neumoljivi svatkovićevi zahtjevi za identitetskom ekspresijom. Njihov je posao da neutraliziraju eshatološki naboj kojim odzvanjaju neki od tih zahtjeva i da stvore 
misaone obrasce koji bi pomogli svatkoviću da se snađe u zbunjujućem prelaženju između protuslovnih povijesti koje istovremeno nastanjuje. U ovome se ogleda zanimljiv pomak od epistemološke "apatije" i etike nepripadnosti, koju je Biti preporučivao krajem osamdesetih kao nužan uvjet teorijske dosljednosti, ka nekoj vrsti političke estetike u kojoj je pažnja usmjerena na pragmatična "razlučivanja", odnosno u kojoj intelektualac postaje neka vrsta kustosa, tumača "finih razlika", empatični life coach koji očajnom svatkoviću ne nameće, već pomaže da realizira protuslovne identitete koji ovaj već ionako nastanjuje. Intelektualac dakle, unutar kulturne sfere, ne pristaje na proročanstvo prosvjetiteljske racionalnosti, već aktivira znatno skromniju, vrtlarsku phronesis koja postepeno može pomoći da se stvore uvjeti međusobne razumljivosti identitetske kompleksnosti pojedinaca, ili barem uvjeti za razumljivost prava na ekspresiju identitetske kompleksnosti.

Ovakva kulturalistička zamisao, usprkos proklamiranoj brizi za svatkovićevu protuslovnost i pritiske kojima je izložen, ipak zakazuje upravo u ovoj svojoj primarnoj misiji i na svatkovića projicira problematiku karakterističnu za svoju partikularnu (klasnu) poziciju. Jer kao što pokazuju najnovija društvena istraživanja početaka postsocijalističke tranzicije ${ }^{17}$, raspad Jugoslavije i nagla uspostava hegemonije etnonacionalizma nisu rezultat fatalne erupcije, iznenadnog loma koji se mora tumačiti kao povratak potisnutog (identiteta). Umjesto toga, ovo krvavo povijesno iskustvo rezultat je kulminacije složene društvene dinamike u kojoj se "identitetski poriv", kanaliziran kroz etnonacionalističku formu, mora shvatiti kao čista kontingencija, logična, ali heteronomna adaptacija na dinamiku promjene materijalnih uvjeta u kojima se odvija društvena reprodukcija. Da bi se uvidjelo koliko je problematično uzimati identitet kao okosnicu objašnjenja procesa raspada jugoslavenske federacije, ne treba čak ni osluškivati isuviše pažljivo, dovoljno je doslovce pogledati što kaže svatković kad ga se pita koji su mu zapravo historijski prioriteti: u istraživanju jav-

17 U radu “Jugoslavensko radništvo u tranziciji: ‘Borovo' 1989.” Sven Cvek, Snježana Ivčić i Jasna Račić opisuju transformaciju tranzicijskih društvenih sukoba čiji je karakter krajem osamdesetih primarno klasni, u sukobe početkom devedesetih čiji karakter postaje etnonacionalni. Pritom analiziraju strukturne promjene iz tog perioda (npr. ukidanje samoupravljanja) te, kako pišu u sažetku rada, "materijalne i ideološke uvjete za podjele među radnicima 'Borova', koje u tom trenutku nemaju etnički/nacionalni predznak, već se stvaraju oko problema raspodjele sve oskudnijih materijalnih resursa" (Cvek et al. 2015: 7). 
nog mnijenja koje je za tjednik Danas u Hrvatskoj u ljeto 199o., dakle pred sam rat kad su tenzije već itekako bile prisutne, proveo politolog Dejan Jović, prioritetni politički problemi su "ekonomija" i "socijalni problemi” na prvom i drugom mjestu, a prvi problem koji je moguće dovesti u vezu s identitetom - iako i tu treba primijetiti da se vjerojatno radi o političko-ekonomskom, a ne kulturnom konceptu - jest treći po redu, "suverenitet Hrvatske". Prvi eksplicitno identitetski problem, "međunacionalni odnosi u Hrvatskoj", tek je peti (Jović 1990: 26-7). Dopustimo si stoga i završnu vulgarnost i sjetimo se Černiševskog koji nas podsjeća da svatković, ako ga zaista pitamo, obično posve trijezno odgovori: "najprije kobasice, a tek onda Shakespeare".

Upravo nam, dakle, pragmatična usmjerenost mišljenja sugerira da zabrinutost za svatkovićev kompleksni identitet, ono što Biti naziva trijeznom pragmatičnošću intelektualca, ne može biti nego neka vrsta dimne zavjese, ideološke projekcije intelektualne klase koja traži uporišnu točku za projekt poljuljan kataklizmom rasapa prosvjetiteljske kulture i njenih institucija u osvit kapitalističke postmoderne na periferiji.

\section{Identitetska forma kao proizvod}

Na kraju, pokušajmo sažeti sve što je dosad rečeno u odgovoru na sljedeće pitanje: kako u širem historijsko-materijalističkom okviru, koji smo naznačili na početku, objasniti simptomatiku teorijskih nedosljednosti domaće humanistike i brzi povratak formalizma/imanentizma na pozornicu s koje je svojevremeno tek bio sišao?

Prvo, književni formalizam u centru svjetskog sistema, tj. u Sjedinjenim Američkim Državama, kao dominanta u akademskom polju nestaje i mjesto ustupa poststrukturalističkoj eksploziji otprilike točno u trenutku u kojem se prvotni poslijeratni transnacionalni mehanizam $\mathrm{i}$ institucionalni okvir akumulacije kapitala ${ }^{18}$ destabilizira i zamjenjuje novim režimom akumulacije u kojem ključnu ulogu ima globalna fluktuacija financijskog kapitala. U tom trenutku počinju cirkulirati i postmoderni koncepti diskursa i fluidnog identiteta kao jedan od izraza onog što je Fredric Jameson nazvao "kulturnom logikom kasnog kapitalizma”. U centru svjetskog sistema, dakle, promjena režima akumulacije iz modernog fordističkog u postmoderni post-fordistički,

$18 \mathrm{Za}$ temeljit pregled povijesti političke ekonomije tog perioda i jaku tezu o učvršćivanju regulatornog okvira za transnacionalnu akumulaciju kapitala prema modelu i pod ključnim utjecajem američke države, vidi Panitch i Gindin 2014. 
koincidira s eliminacijom formalizma kao legitimne metode znanstvenog mišljenja književnosti/kulture. No, kao što smo već rekli slijedeći Nilgesa, formalizam na početku 21. stoljeća u centru doživljava zamjetan come back, a objašnjenje za to moguće je još jednom pronaći u vezi između filozofske i strukturne forme, odnosno moguće je težnju za povratkom stabilnim disciplinarnim strukturama u američkoj humanistici objasniti kao jednu moguću filozofsku formu odgovora na krizu humanistike u korporativnom sveučilištu u periodu strukturne krize sustava. Nilges na kraju smjelo zaključuje kako se "učinak strukturne krize na društvenu dimenziju na filozofskoj razini” može u filozofiji registrirati kao "efektivno i konačno pokapanje postmodernog projekta” (Nilges 2009: 75). Drugim riječima, neoformalizam označava obrambeni mehanizam humanističkog mišljenja suočenog $\mathbf{s}$ krizom disciplinarnog identiteta i institucionalne stabilnosti. Forma, kao utočište ne od postmoderne, već od kolapsa postmoderne, nostalgična je reminiscijencija, nemoguća želja za povratkom u sigurne vode socijalne države i autonomije znanstvene proizvodnje.

Čini se da se sličan zaključak može povući i u domaćem kontekstu: s određenim lokalno uvjetovanim razlikama u temporalitetu, formalizam/imanentizam dominira kao forma mišljenja kulturne proizvodnje više-manje tijekom čitavog perioda socijalističke države blagostanja. Krajem osamdesetih i početkom devedesetih on je u akademskom polju doveden u pitanje, no rezidualni oblici formalizma/imanentizma gotovo istovremeno s njegovim kritičkom diskreditacijom na području književnosti vraćaju se kao preferirani model kulturalističke analize nacionalnog identiteta. Kod nas se, dakle, kulturološki povratak formalizmu/imanentizmu ne događa kao simptom kolapsa postmoderne, već upravo suprotno, kao simptom njenog ranijeg trijumfa koji se na periferiji društveno registrirao kao raspad socijalističkog modela i federativne multietničke države. No u oba slučaja, formalizam/ imanentizam javlja se kao odgovor na ozbiljne krize institucionalnog okvira kojim se regulira proizvodnja znanja.

Ako je socijalistička država blagostanja sa svojim prosvjetiteljskim institucijama materijalna pretpostavka nastanka ${ }^{19}$ i reprodukcije for-

19 Ovo potvrđuje i sama Oraić Tolić u jednom od tekstova o Zagrebačkoj školi u kojem navodi kako je "izgradnja institucija” jedan od ključnih aspekata škole, te dodaje i sumornu spekulaciju o tome kako provedba Bolonjskog procesa na zagrebačkom Filozofskom fakultetu, koji je bio krovna institucija djelatnosti Zagrebačke škole, znači da su "tom Fakultetu u dosadašnjem obliku dani, čini se, odbrojani.” (2004: 24). 
malizma/imanentizma, njena destabilizacija u fazi propasti socijalizma i integracije novonastale države u svjetski kapitalistički sistem, motivira reaktivaciju formalističke analitike u pokušaju da se ponudi nostalgično kulturno rješenje za širi institucionalni problem u kojem se nalazi humanistika. Koncepti autonomne identitetske ekspresije postaju lijek za nelagodu kapitalističke supsumcije. A da ta nelagoda zaista postoji potvrđuju nam i analogni strahovi Bitija i Oraić Tolić od kulturne dinamike kapitalističke globalizacije ${ }^{20}$. Povratak formalizmu/imanentizmu, proizlazi iz ovoga, nije dakle teorijska omaška ili metodološka nedosljednost, već simptom kulturne (a uz to i institucionalne i epistemološke) nesigurnosti u vezi sudbine nacionalnog identiteta - odnosno kulturne proizvodnje koja se odvija u okviru nacije-države i uvelike se oslanja na nacionalne tradicije, kanone i institucije - kod građanskih humanističkih intelektualaca na periferiji.

Ako je u centru s vrhuncem u zadnja dva desetljeća dvadesetog stoljeća kulturna logika kasnog kapitalizma svoj izraz našla u pluralističkoj politici identiteta i mikroidentitetskom ekspresivizmu (da bi onda posljednja strukturna kriza motivirala povratak formalizmu $\mathrm{i}$ tradicionalnim disciplinarnim granicama), na periferiji je $\mathrm{u}$ istom periodu analogna logika svoj izraz našla u ekskluzivnom etnonacionalizmu i formalizmu/imanentizmu kao njegovom teorijskom izrazu u kulturologiji. Koncept identiteta u suvremenoj kulturološkoj aparaturi na postsocijalističkoj, postjugoslavenskoj periferiji u tom kontekstu čvrsto je vezan sidrom nacije i rijetko je prema uzoru na modele iz centra dosljedno koncipiran kao otvoren i fluidan. Budući da je formiran kao simptom postsocijalističke kataklizme, kao takav i dalje funkcionira kao imaginarno utočište od njenih posljedica. Ovako postavljena stvar, rekao bih, dobro nadopunjuje teoretizaciju postmodernih nacija koju je ponudio Rastko Močnik prema kojem se u postmoderni ne konstituira izvorna devetanestostoljetna nacija, već nasilna identitetska zajednica. Kako piše Dinko Kreho tumačeći Močnika, taj identitetski nacionalizam

20 Biti tako piše, uspostavljajući analogiju između "volje za samoodređenje" u zemljama Srednje i Istočne Europe i "prenadraženih [...] etničkih grupnih identiteta” u SAD-u: "Svakako, obje te pojave valja u jednakoj mjeri promatrati kao reakciju identifikacijske potrebe u širokim slojevima stanovništva na pritisak rastućih političkih i gospodarskih sistema koji ih sile na neograničenu interakciju [...]” (Biti 1994: 126-7). Mišljenje Oraić Tolić na temu globalizacije već je citirano ranije u ovom tekstu. 
nema prosvjetiteljskih pretenzija: on se rukovodi idealom male, paranoične zajednice, u kojoj je široka i inkluzivna podloga nacionalne tradicije [iz 19. stoljeća] zamijenjena monolitom nacionalnog identiteta. Umjesto političke borbe, identitetski nacionalizam propisuje homogenu nacionalnu kulturu kao okvir u kojem se sve političke razlike imaju dokinuti [...] Sukladno tome, uloga književnosti nije, kao u romantičarskoj predodžbi, da otvara teren za politiku — nego, posve suprotno, da bude zamjena za nju. [...] univerzitetske katedre bosnistike, kroatistike, srbistike, itd. danas ne predstavljaju mjesta gdje se, u romantičarskom maniru, ‘izmišlja tradicija'. One nisu zainteresirane za izgradnju nacionalnog mita, nego tek za opsesivno istraživanje skliske, neuhvatljive supstance nacionalnog identiteta. (2015: 28)

Koncept nacije u kojem se proturječja i razlike dokidaju u estetiziranoj autonomnoj cjelini svakako je neugodno blizak poznatoj Benjaminovoj tezi o estetizaciji politike karakterističnoj za fašizam. No ovdje ga treba promatrati u njegovoj konkretnoj društvenoj funkciji: za postsocijalističku periferiju ovaj koncept je prikladan ne samo zbog svoje ideološko-disciplinarne uloge, već i zbog toga što otvara priliku za izgradnju kulturne platforme za integraciju u globalno kapitalističko tržište. Kao što smo već ustvrdili, nakon devastacije industrijske proizvodnje i uz nju vezanih klasnih pozicija u procesima restauracije kapitalizma i integracije u globalnu podjelu rada, utješna fantazma o nacionalnom identitetu gotovo da i jest jedina stvar koju je na postsocijalističkoj periferiji još moguće proizvoditi ${ }^{21}$. S fatalnom nelagodom ove činjenice moguće se suočiti jedino ako je promotrimo u njenoj strukturnoj dimenziji i historijskoj uvjetovanosti, i jedino ako demistificiramo koncept identiteta definirajući ga u kontingenciji njegove

21 Ova nezgodna činjenica osviještena je i na institucionalnim razinama s kojih se u najširem smislu regulira oblik, razvoj i funkcija proizvodnje znanja i nacionalne kulture. Pa tako državni Plan razvoja istraživačke $i$ inovacijske infrastrukture u Republici Hrvatskoj, dokument koji je 2014. godine proizvelo Ministarstvo znanosti, obrazovanja i sporta navodi: "Kultura leži u središtu svakog razvoja. Ona obilježava pojedina društva i društvene skupine. Sustavnoj brizi o hrvatskoj baštini mora se stoga posvetiti posebna pažnja kako bi se u globalizacijskim procesima sačuvao hrvatski identitet. Kulturni sektor može postati i pokretač gospodarskih aktivnosti te, povezan s gospodarstvom, posebice turizmom, pomoći općem gospodarskom razvoju i zapošljavanju” (MZOS 2014: 33). 
društvene uloge, odupirući se izazovima estetskih tumačenja. To je pak temeljito izvedivo jedino unutar dosljedne historijsko-materijalističke eksplanatorne matrice prema kojoj bi se trijezna orijentacija humanističkih istraživanja trebala kretati. đI 


\section{Literatura}

Biti, Vladimir. 1989. Pripitomljavanje drugog: Mehanizam domaće teorije. Zagreb: Hrvatsko filozofsko društvo.

Biti, Vladimir. 1994. Upletanje nerečenog: Književnost/povijest/teorija. Zagreb: Matica hrvatska.

Brenner, Robert i Mark Glick. 1991. “The Regulation Approach: Theory and History”. U: New Left Review I, 188: 45-119.

Car, Milka. 2009. "Književnost i povijesni svijet Zdenka Škreba i teorija fikcionalnosti”. U: Umjetnost riječi 53, 3-4: 153-167.

Cvek, Sven, Snježana Ivčić i Jasna Račić. 2015. "Jugoslavensko radništvo u tranziciji: 'Borovo' 1989.”. U: Politička misao 52, 2: 7-34.

Callinicos, Alex. 2006. Universities in a neoliberal world. London: Bookmarks.

Dukić, Davor. 1995. "Promišljanje književne historiografije u hrvatskoj znanosti o književnosti”. U: Trag i razlika: Čitanja suvremene književne teorije. Ur. Vladimir Biti, Nenad Ivić i Josip Užarević. Zagreb: MD \& Hrvatsko društvo za društvene i humanističke znanosti.

Dukić, Davor. 2009. "Kultura-zapostavljen pojam u počecima moderne hrvatske znanosti o književnosti”. U: Umjetnost riječi 53, 3-4: 137-152.

Dutton, Denis. 2009. The Art Instinct: Beauty, Pleasure, and Human Evolution. New York: Bloomsbury Press.

Gupta, Suman, Jernej Habjan i Hrvoje Tutek. 2016. Academic Labour, Unemployment and Global Higher Education: Neoliberal policies of Funding and Management. London: Palgrave Macmillan.

Jessop, Bob i Ngai-Ling Sum. 2006. Beyond the Regulation Approach: Putting Capitalist Economies in Their Place. Cheltenham: Edward Elgar Publishing. Jović, Dejan. 199o. "Što mislite da je prioritetno u programu nove Vlade?". U: Danas: informativno-politički tjednik 9, 437: 26-27.

Krašovec, Primož. 2011. "Realna sumpsumcija u hramu duha: Klasna borba u univerzitetskom polju”. U: jugoLink. pregled postjugoslovenskih istraživanja, $1,1,33-54$.

Kreho, Dinko. 2015. "Regija i(li) Jugoslavija: 'Regionalna komparatistika između tržišta, kulture i politike”. U: k. - studentski časopis za književnost, književnu i kulturalnu teoriju 8, 12: 2237.

Levine, Caroline. 2015. Forms: Whole, Rhythm, Hierarchy, Network. Princeton: Princeton University Press.

Levinson, Marjorie. 2007. "What Is New Formalism?". U: PMLA 122, 2: $558-569$.

Lesjak, Carolyn. 2013. "Reading Dialectically”. U: Literary Materialisms. Ur. Mathias Nilges i Emilio Sauri. New York: Palgrave Macmillan.

Mikulić, Borislav. 1993. "Semiotika i panslavizam. O mjestu Evrope u 
neonacionalističkom diskursu Istoka”. U: Filozofija u pretilo doba. Eseji o figurama reprezentacije filozofije naspram politike (dio IV), Treći program hrvatskog radija, br. 40, 1993, str. 100-112 (Kronika devedesetih, ožujak 1993, ur. Kiril Miladinov). Sada u: B. Mikulić. 2015. Trg izgubljene Republike $i$ druge uzorite priče 9oih, Zagreb: Arkzin, 103-108.

Ministarstvo znanosti, obrazovanja i sporta. 2014. Plan razvoja istraživačke $i$ inovacijske infrastrukture u Republici Hrvatskoj. Internet. 24. studeni 2016. Moretti, Franco. 2005. Graphs, Maps, Trees: Abstract Models for a Literary History. London: Verso.

Nilges, Mathias. 2009. "Marxism and Form Now". U: Mediations 24, 2: 66-89. Oraić Tolić, Dubravka. 2004. Aleksandar Flaker i Zagrebačka škola. U: Oko književnosti: Osamdeset godina Aleksandra Flakera. Ur. Josip Užarević, Zagreb: Disput, str. 21-38.

Oraić Tolić, Dubravka. 20o5. Muška moderna i ženska postmoderna: Rođenje virtualne kulture. Zagreb: Naklada Ljevak.

Oraić Tolić, Dubravka. 2009. “Viktor Žmegač i Zagrebačka škola”. U: Umjetnost riječi 53, 3-4: 185-206.

Panitch, Leo i Sam Gindin. 2012. The Making of Global Capitalism: The Political Economy of American Empire. London: Verso.

Roggero, Gigi. 2011. The Production of Living Knowledge: The Crisis of the University and the Transformation of Labor in Europe and North America. Prev. Enda Brophy. Philadelphia: Temple University Press.

Slaughter Sheila i Gary Rhoades. 2004. Academic Capitalism and the New Economy: Markets, State, and Higher Education. Baltimore: The Johns Hopkins University Press.

Szadkowski, Krystian. 2013. "University's Third Mission as a Challenge to Marxist Theory". U: The Center for Public Policy Studies (Poznan University), Research Paper Series 36. Internet. 2. prosinca 2016.

Škreb, Zdenko. 1998. Književne studije i rasprave. Zagreb: Alfa.

Udier, Sanda Lucija. 2011. "Jezik književnosti u modernome hrvatskome jezikoslovlju i književnoj znanosti”. U: Kolo 19, 5-6: 135-178.

Užarević, Josip. 1995. “Znanost o književnosti i teorija interpretacije”. U: Trag i razlika: Čitanja suvremene književne teorije. Ur. Vladimir Biti, Nenad Ivić i Josip Užarević. Zagreb: MD \& Hrvatsko društvo za društvene i humanističke znanosti.

Užarević, Josip. 2015. "Zagrebačka stilistička škola i ruski formalizam”. U: Forum 4-6: 512-551.

Warwick Research Collective. 2015. Combined and Uneven Development: Towards a New Theory of World Literature. Liverpool: Liverpool University Press. 